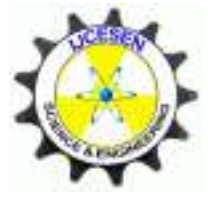

Copyright $($ I IJCESEN
International Journal of Computational and

Experimental $\boldsymbol{S}$ cience and $\boldsymbol{E N g i n e e r i n g}$

(IJCESEN)

Vol. 7-No.1 (2021)pp. 1-8

http://dergipark.org.tr/en/pub/ijcesen

ResearchArticle

\title{
Prediction of Heart Attack Using Fuzzy Logic Method and Determination of Factors Affecting Heart Attacks
}

\author{
Seher ARSLANKAYA ${ }^{1 *}$, Tuba Miraç ÇELIK ${ }^{2}$ \\ ${ }^{1}$ Sakarya University, Engineering Faculty, Industrial Engineering Department, 54187, Sakarya-Turkey \\ * Corresponding Author : aseher@ @akarya.edu.tr - ORCID:0000-0001-6023-2901 \\ ${ }^{2}$ Sakarya University, Engineering Faculty, Industrial Engineering Department, 54187, Sakarya-Turkey \\ tuba_celik1999@ hotmail.com - ORCID:0000-0001-6023-2901
}

\section{Article Info:}

DOI: $10.22399 /$ ijcesen. 837731

Received : 08 December 2020

Accepted : 18 March 2021

\section{Keywords}

Fuzzy Logic

Heart attack

Regression Analysis

Artificial intelligence

\begin{abstract}
:
As a result of the researches, it has been revealed that heart attack is the number one cause of death in the world. This problem will continue to increase, especially today and in the future. In this study, a heart attack was predicted by considering the factors affecting heart attack. Due to the uncertain conditions in heart attack, the fuzzy logic method, which is frequently used in healthcare, was used and expert opinions were taken into account in the model created. 576 rules were defined using the Mamdani fuzzy inference method. The study was tested with 10 patient data and the results were compared with the actual values. In addition, multiple regression analysis was performed, variables that had a significant effect on heart attack were determined, and the relationship between dependent and independent variables was examined. It was shown in the study that dependent variables explained the independent variable by $41.9 \%$ thanks to the multiple regression analysis. The regression equation obtained in line with these results significantly predicted the heart attack and the effect levels of the independent variables were determined.
\end{abstract}

\section{Introduction}

When a sudden blockage occurs in the arteries feeding the heart for any reason, the heart muscle cannot get enough oxygen and causes damage to the heart tissue. Substances such as fat and cholesterol accumulate in the artery walls responsible for blood flow and form structures called plaques. These plaques multiply as time passes and cause cracks on them by narrowing the vessels. Clots occur in these cracks, occlude the vessels and cause a heart attack [1].Tobacco use, excessive alcohol consumption, high cholesterol and fat, age (men over 40, women over 50), diabetes, obesity, use of illegal drugs, high blood pressure, chronic high levels of stress, previous heart attack, arrhythmia are important risk factors $[2,3,4]$. The risk of heart attack increases after the age of 40 in men and 50 in women, and women are less likely to have a heart attack than men [1]. Among family members, people who have had a previous heart attack or have a history of heart disease, the elderly and men are more likely to have a heart attack than other risk factors [5]. The main symptom seen in a heart attack is heart pain in the chest. Apart from this area, pain is felt everywhere from the stomach to the jaw or teeth, from the shoulder blade to the right and left arm, fingers and wrists. Symptoms such as shortness of breath, excessive sweating, dizziness, nausea or vomiting, restlessness, and feeling of depression may be experienced [1,6,7]. The World Health Organization (WHO) states that heart disease is the \# 1 cause of death worldwide. Approximately 17 million people die from these diseases each year, representing $31 \%$ of global deaths. $85 \%$ of these deaths are caused by heart attack and stroke [8]. WHO stated that $36 \%$ of deaths that will occur in 2020 will be caused by heart diseases [9]. In addition, WHO stated that heart diseases increase the risk of Covid-19. According to a recent study, it was revealed that $43 \%$ of those with Covid-19 in Spain have heart disease [10]. In the Turkey Statistical Institute (TSI) in total deaths, according 
to the measurement data, it is observed that the increasing trend of heart disease. Heart diseases are in the first place among the total deaths with $40 \%$ in $1989,45 \%$ in $1993,40 \%$ in $2009,39.6 \%$ in 2013 and $40.4 \%$ in 2014.In 2030, it is estimated that cardiovascular diseases will be 22.2 million [11]. Considering the mortality rates due to heart diseases, it is seen that our country ranks first among European countries [12]. Many studies have been conducted in the literature concerning many factors that cause heart disease. Fuzzy logic is one of these studies. The concept of fuzzy logic was introduced by Zadeh in 1965 [13]. Fuzzy logic, which is a control system, is in the form of range to point or range to interval [13]. Kumar and Kaur (2013) created a fuzzy model for heart disease risk prediction using the Mamdani inference method [14]. Lee and Wang (2011) conducted a study on diabetes using fuzzy expert system[15]. Rustempasic and Can (2013) tried to diagnose Parkinson's disease using the fuzzy C-mean clustering method and pattern recognition method [16]. Samuel, Omisore, and Ojokoh (2013) conducted a study diagnosing typhoid fever using fuzzy logic [17]. Biouki, Turksen, and FazelZarandi (2015) diagnosed Thyroid disease using fuzzy expert system [18]. Thakur, Raw, and Sharma (2016) diagnosed Thalassemia using the Mamdani fuzzy inference system [19]. Saikia and Dutta (2016) predicted dengue disease using fuzzy inference system [20]. Apart from these studies, many studies have been conducted in the literature as a result of the increase in mortality rates due to heart diseases. Different techniques were used in these studies. Torun (2007) designed a hierarchical fuzzy expert system to determine the patient's risk of coronary heart disease [21]. The 10-year risk of the patient was determined in the study. As a result of the study, the risk ratio was given to the user and the treatment method was recommended. Palaniappan and Awang (2008) developed a prototype heart disease prediction system using data mining techniques (decision trees, pure Bayesian and neural network) [22]. Patil and Kumaraswamy (2009) proposed a system that predicts heart attack using a multilayer perceptron neural network [23]. Adeli and Neshat (2010) designed a fuzzy system with 13 inputs and conducted a study to reveal heart disease, and as a result of this study, they reached $94 \%$ accuracy [24]. Bhatla and Kiran (2012) conducted a study to diagnose heart diseases using data mining and fuzzy modeling[25]. Devi and Anto (2014) conducted a study to diagnose coronary artery disease by designing a fuzzy expert system [26]. A smart health system has been proposed for heart disease prediction using deep learning and fusion approaches [27]. In this study, it was tried to predict heart attack by using fuzzy logic method. While establishing the model, seven input data and one output data were used. Entries; Exercise-induced St depression (oldpeak) according to age, gender, type of chest pain $(\mathrm{Cp})$, cholesterol, fasting blood glucose (Fbs), exercise-induced pain (Exang) and rest. The desired output is heart attack prediction. Afterwards, the variables that had a significant effect on heart attack were determined by performing regression analysis and the results obtained were interpreted. In the second part of the study, fuzzy logic method is explained, application is made in third parts, and the conclusion part is included in the fourth part.

\section{Material and Method}

The concept of fuzzy logic was first introduced in 1965 by Prof. Dr Zadeh [13]. It emerged with the "FuzySets" article published by Lotfi A. Zadeh $[13,21]$.Using the data related to the study to be conducted and at the same time benefiting from the professional experiences of the people, processing the obtained data with algorithms and using mathematical equations depending on the rules to be written is defined as "Fuzzy Logic" [28,29,30].

Classical set theory and fuzzy set theory are different from each other. While $\{0,1\}$ notation is used in classical sets, the interval [0-1] is used in fuzzy sets. Because in classical set theory, an entity is either an element of that set or it is not. In fuzzy set theory, each entity receives a membership degree in the range [0-1].Membership degrees are indicated by membership function $\mu$ (x) [31]. According to this information, the membership degree of element $\mathrm{x}$ in fuzzy set $\mathrm{A}$ is,

$$
\mu \mathrm{A}(\mathrm{x}): \mathrm{x} \rightarrow[0,1] \text { ie } 0 \leq \mu \mathrm{A} \leq 1
$$

shown in the form. The expression $\mu \mathrm{A}=0$ indicates that the $\mathrm{x}$ element does not belong to the fuzzy A set, and the expression $\mu \mathrm{A}=1$ indicates that the $\mathrm{x}$ element belongs to the fuzzy A set [32].

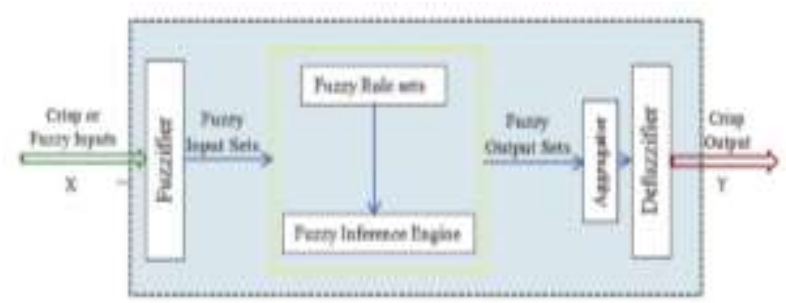

Figure 1. General structure of the fuzzy logic model [33].

The general structure of the fuzzy logic model is given in Figure 1. It consists of four components. These are: blur, rule base, inference engine, and clarification. 
1. Blurring: Converts the input values to fuzzy values using the membership function. This process varies according to the membership function [21].

2. Rule Base: It is the relationship between inputs and outputs using various operators (fuzzy and implication operators) and interpreting the rules [34].

3. Inference Engine: In this section, rules based on rules are interpreted and fuzzy outputs are created [35].

4. Clarification: Incoming blurred information is clarified and converted into numbers [36].

First, entries are blurred using membership functions. Using fuzzy input and output values, fuzzy rules to be used in the solution of the problem are created and inference is performed with these rules. Finally, fuzzy information is clarified and turned into numbers [29]. Fuzzy logic has found wide application in many areas. The reason for this is the easy and useful solution-finding approach it provides in solving problems [37].It has been the subject of many fields such as medicine, manufacturing and engineering [38]. Another reason for its use in large areas is that it can model uncertain events, unclear data and functions by using expert opinions [39].Fuzzy logic is very important in the field of health, so it has many applications in medicine [40]. Problems are solved by using fuzzy sets for unclear conditions in medicine [41].

\section{Results}

This study was conducted using fuzzy logic in line with the data obtained from Kaggle. Fuzzy Logic Model was created using 7 input parameters and 1 output parameter, and it was estimated whether individuals would have a heart attack or not. Input parameters are St depression induced by exercise according to age, sex, type of chest pain, cholesterol, fasting blood glucose, exercise-induced pain, and listening. The output parameter is the heart attack prediction. All inputs are factors that will affect a heart attack. Input and output parameters are shown in Table 1. Triangle membership function (trimf) was used for age, gender, Chol, Fbs, Exang, Oldpeak and Heart attack prediction variables, and trapezoidal membership function (trapmf) was used for $\mathrm{Cp}$ variable. Since each variable is divided into classes within itself, the classes are expressed with linguistic variables when creating membership functions. Table 2 shows linguistic variables. Membership functions of the input parameters are shown from Figure 2 to Figure 8. In Figure 9, membership function of output parameter is given. In this study, Mamdani's Max-Min fuzzy inference method was used [42].
Centroid (Center of Gravity Method) method was used in the defuzzification stage.

Table 1. Input and output parameters and their meanings

\begin{tabular}{|l|l|}
\hline Parameters & \multicolumn{1}{|c|}{ Meanings } \\
\hline Age & $\begin{array}{l}\text { It is divided into 3 classes as young, } \\
\text { middle-aged and elderly. }\end{array}$ \\
\hline Gender & Men and women \\
\hline Cp & $\begin{array}{l}\text { It is divided into 4 classes: } \\
\text { Typical pain, Atypical pain, } \\
\text { No pain, and Asymptomatic pain. }\end{array}$ \\
\hline Chol & $\begin{array}{l}\text { It is divided into 3 classes as low, } \\
\text { medium and high. }\end{array}$ \\
\hline Fbs & $\begin{array}{l}\text { It is divided into 2 classes as normal and } \\
\text { high. }\end{array}$ \\
\hline Exang & $\begin{array}{l}\text { It means pain induced by exercise. It is } \\
\text { divided into 2 classes: no pain and pain. }\end{array}$ \\
\hline Oldpeak & $\begin{array}{l}\text { It is ST depression induced by exercise } \\
\text { compared to listening. It is divided into 2 } \\
\text { classes as 2 mm below and 2 mm above. }\end{array}$ \\
\hline $\begin{array}{l}\text { Heart Attack } \\
\text { Prediction }\end{array}$ & $\begin{array}{l}\text { Output parameter. It is divided into two } \\
\text { classes. Heart attack and heart attack } \\
\text { proof }\end{array}$ \\
\hline
\end{tabular}

Table 2. Classification of parameters

\begin{tabular}{|c|l|}
\hline Parameters & \multicolumn{1}{|c|}{ Linguistic variables } \\
\hline \multirow{3}{*}{ Age } & $\begin{array}{l}\text { 40 years and under } \rightarrow \text { Young } \\
\text { 40-60 age } \rightarrow \text { Middle age } \\
\text { 60 years and older } \rightarrow \text { Old }\end{array}$ \\
\hline Cinsiyet & $0=$ Woman $1=$ Man \\
\hline \multirow{2}{*}{ Cp } & $\begin{array}{l}0=\text { Typical pain, 1 = Atypical pain, } \\
2=\text { No pain, 3 = Non-symptomatic } \\
\text { pain }\end{array}$ \\
\hline \multirow{2}{*}{ Chol } & $\begin{array}{l}200 \text { and below } \rightarrow \text { Low } \\
200-240 \quad \text { Medium } \\
240 \text { and above } \rightarrow \text { High }\end{array}$ \\
\hline \multirow{2}{*}{ Fbs } & $\begin{array}{l}125 \text { and below } \rightarrow \text { Normal } \\
126 \text { and above } \rightarrow \text { High }\end{array}$ \\
\hline Exang & $0=$ No \\
\hline \multirow{2}{*}{ Oldpeak } & $\begin{array}{l}2 \text { mm and under } \rightarrow 2 \mathrm{~mm} \text { bottom } \\
2 \text { mm and older } \rightarrow 2 \text { mm top }\end{array}$ \\
\hline $\begin{array}{c}\text { Heart attack } \\
\text { prediction }\end{array}$ & $\begin{array}{l}0=\text { No } \\
1=\text { Yes }\end{array}$ \\
\hline
\end{tabular}

First, the data were taken from Kaggle and the input and output parameters to be used in the study were determined. Limit values, linguistic variables and membership functions of these parameters have been created. In order to create the rule base, a relationship between input and output has been established and transferred to the Rule Editor section on the Fuzzy interface. The total number of rules created is 576. After the rule bases are created in the Rule Editor section, the rule index can be seen graphically thanks to the inference screen in the fuzzy interface (Figure 10). 


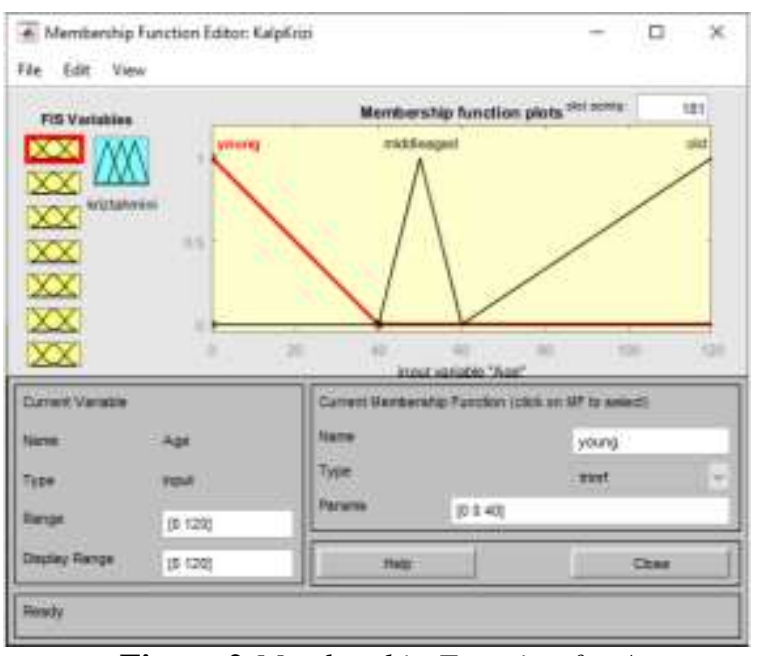

Figure 2.Membership Function for Age

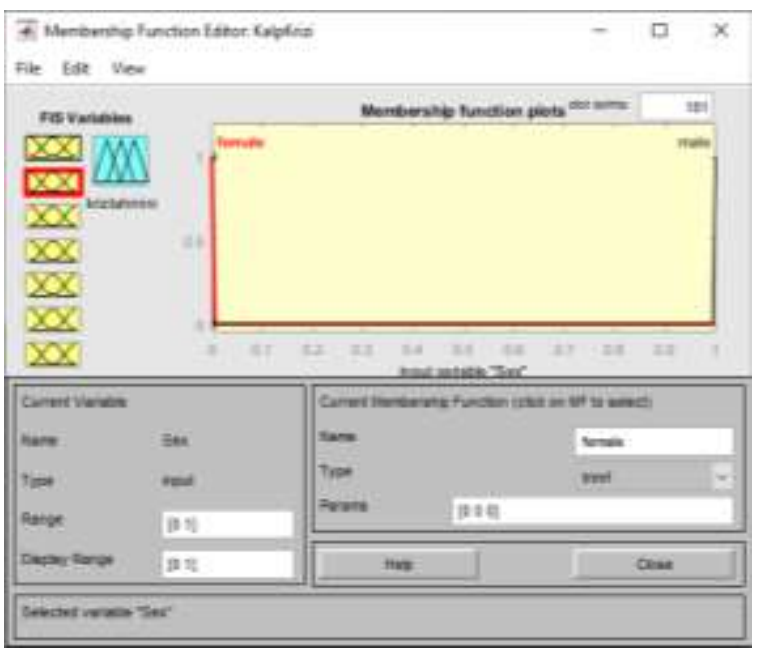

Figure 3.Membership Function for gender

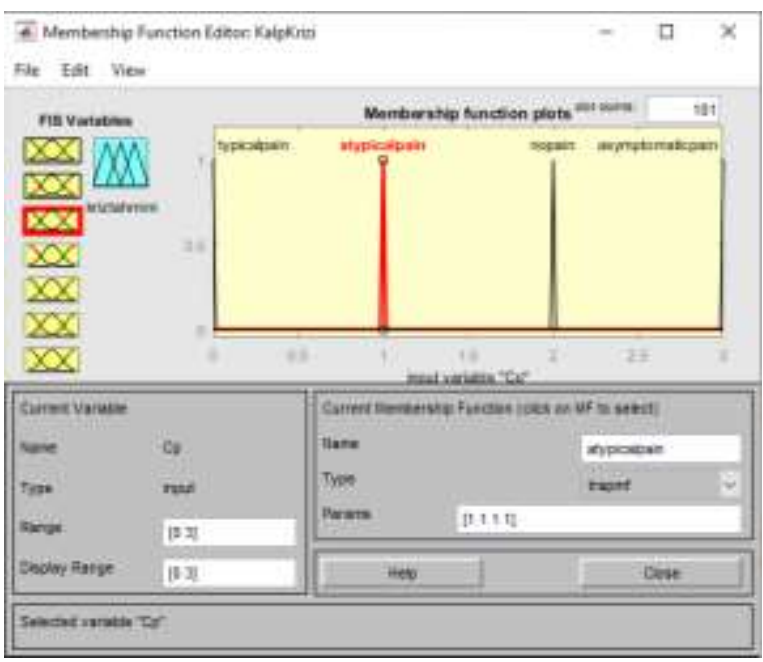

Figure 4. Membership Function for $C p$

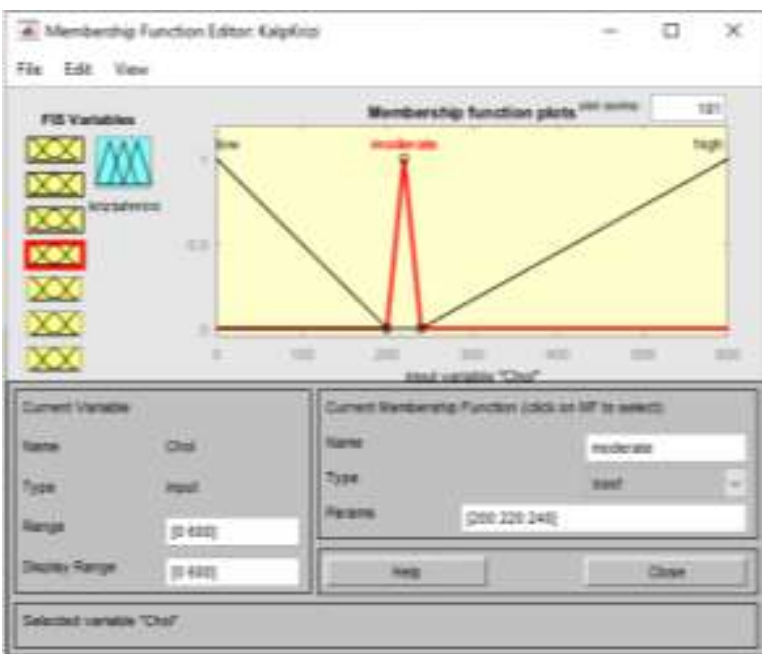

Figure 5. Membership Function for chol

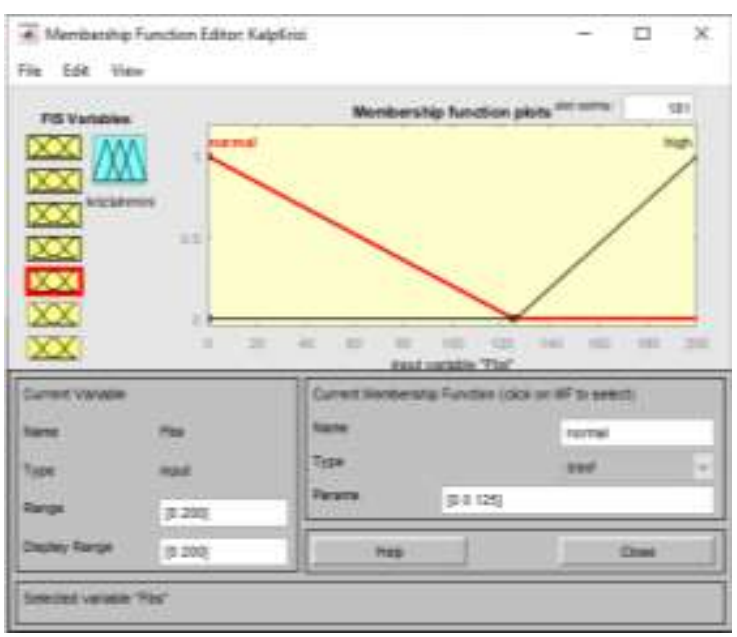

Figure 6. Membership Function for Fbs

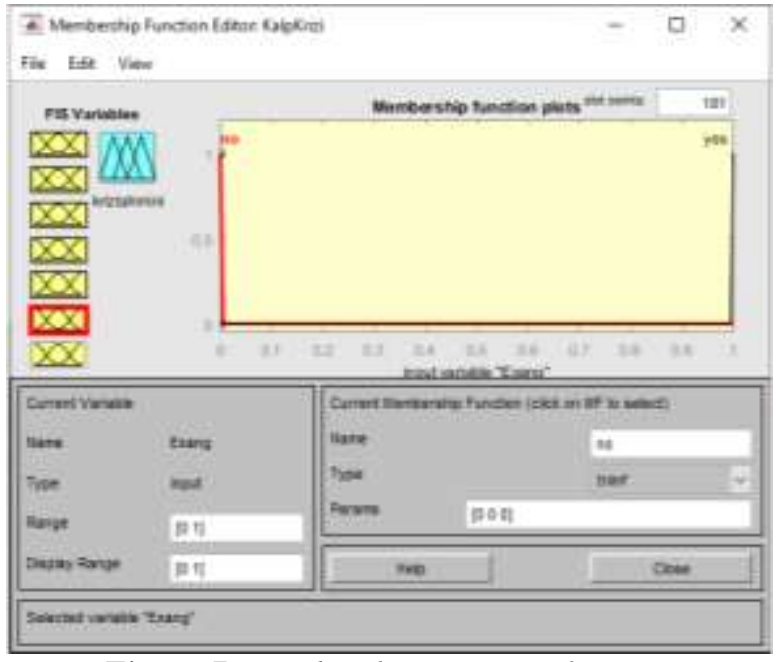

Figure 7. Membership Function for Exang 


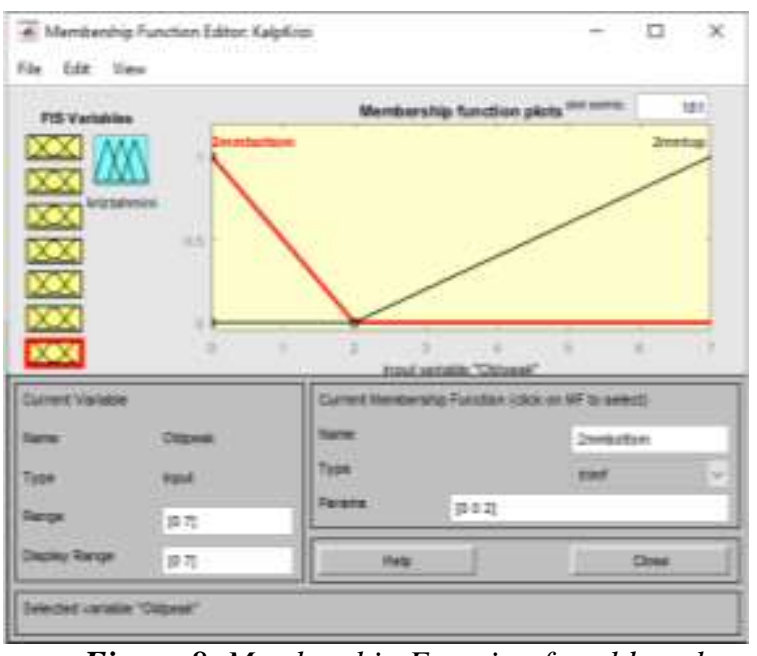

Figure 8. Membership Function for old peak

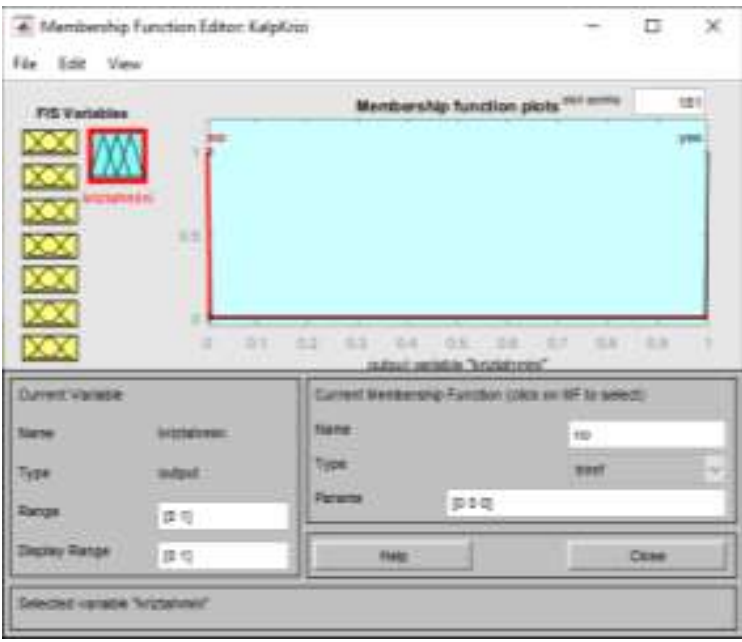

Figure 9. Heart attack Fuzzy Logic Output

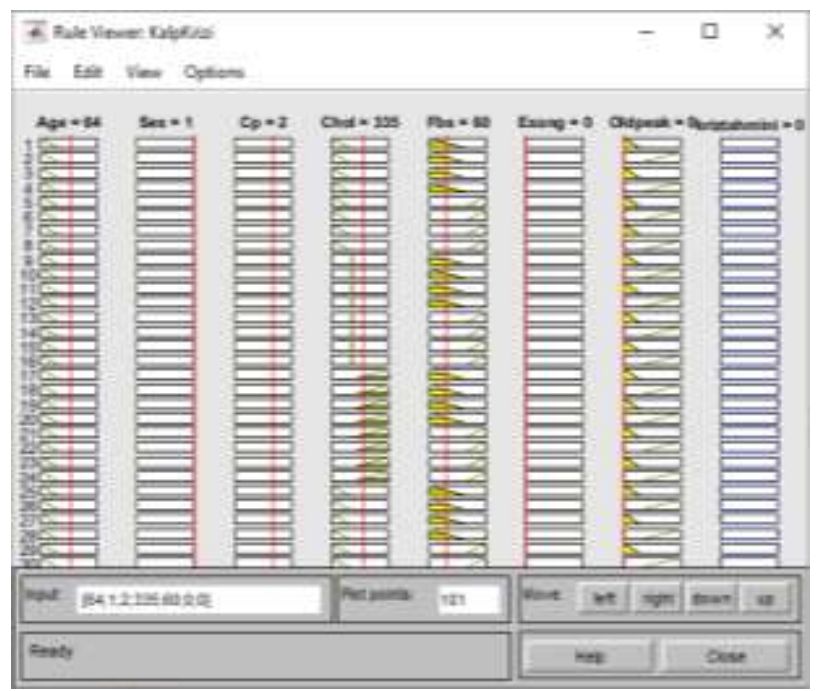

Figure 10. Inference Screen

Thanks to the data entered in the inference screen, whether the individual will have a heart attack or not can be seen in 0 or 1 format. 10 patient input data and heart attack prediction.

It is shown in Table 3.According to the results of the trial performed for 10 patients with the developed fuzzy logic model, all data were correctly estimated.

\subsection{Regression Analysis}

Table 3. Input data and heart attack prediction for 10 patients

\begin{tabular}{|c|c|c|c|c|c|c|c|c|c|}
\hline \multirow[b]{2}{*}{$\stackrel{8}{z}$} & \\
\hline & $\stackrel{\$}{\&}$ & d. & चे & $\stackrel{\bar{\theta}}{\bar{U}}$ & $\frac{n}{x}$ & $\begin{array}{l}\text { 此 } \\
\text { 离 } \\
\text { I. }\end{array}$ & & 焉 & 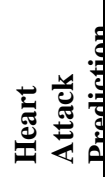 \\
\hline 1 & 63 & 1 & 3 & 233 & 135 & 0 & 2.3 & 1 & 1 \\
\hline 2 & 57 & 0 & 1 & 236 & 110 & 0 & 0 & 0 & 0 \\
\hline 3 & 37 & 1 & 2 & 250 & 72 & 0 & 3.5 & 1 & 1 \\
\hline 4 & 52 & 1 & 2 & 199 & 127 & 0 & 0.5 & 1 & 1 \\
\hline 5 & 44 & 1 & 0 & 120 & 56 & 1 & 2.8 & 0 & 0 \\
\hline 6 & 61 & 1 & 0 & 203 & 85 & 0 & 0 & 0 & 0 \\
\hline 7 & 71 & 0 & 2 & 265 & 140 & 0 & 0 & 1 & 1 \\
\hline 8 & 43 & 1 & 0 & 177 & 120 & 1 & 2.5 & 0 & 0 \\
\hline 9 & 64 & 1 & 2 & 335 & 60 & 0 & 0 & 0 & 0 \\
\hline 10 & 45 & 0 & 0 & 236 & 80 & 1 & 0.2 & 1 & 1 \\
\hline
\end{tabular}

The technique used to examine the relationship between dependent and independent variables is called Regression Analysis [43].

The value of the dependent variable is estimated by using the known values of the independent variables [44].

First, a heart attack prediction was made using fuzzy logic model. Then, multiple regression analysis was performed using dependent (output parameter) and independent variables (input parameters).In Table 4, variables entered in the model are shown in the Variables Entered column. It was stated that a heart attack was predicted using the data obtained from the variables entered.

Table 4. "VariablesEntered / Removed" results

\begin{tabular}{|c|c|c|c|}
\hline \multicolumn{4}{|c|}{ VariablesEntered/Removed $^{\text {a }}$} \\
\hline Model & $\begin{array}{l}\text { Variables } \\
\text { Entered }\end{array}$ & $\begin{array}{l}\text { Variables } \\
\text { Removed }\end{array}$ & Method \\
\hline 1 & $\begin{array}{c}\text { oldpeak, fbs, } \\
\text { chol, cp, sex, } \\
\text { age, exang }\end{array}$ &. & Enter \\
\hline
\end{tabular}

a. DependentVariable: kalpkrizi

b. Allrequestedvariablesentered.

Table 5 shows the multiple correlation value $(\mathrm{R})$, how much the input values explain the variance of the heart attack prediction (R Square), the estimated standard error (Std. Error of the Estimate). It is seen that dependent variables determined according to Table 5 explain the independent variable at a rate of $41.9 \%$. Table 6 Sig. Since its value is below 0.05 , the regression equation obtained as a result of this analysis significantly predicts the heart attack. Table 7 shows the average value, standard deviation and sample number of each variable. Looking at the "Standardized Coefficients Beta" 
Table 5. Model Summary table

\begin{tabular}{|c|c|c|c|c|}
\hline \multicolumn{5}{|c|}{ Model Summary } \\
\hline Model & $\mathbf{R}$ & $\begin{array}{l}\text { R } \\
\text { Square }\end{array}$ & $\begin{array}{l}\text { Adjusted } \\
\text { R Square }\end{array}$ & $\begin{array}{l}\text { Std. Error } \\
\text { of the } \\
\text { Estimate }\end{array}$ \\
\hline 1 &, $658^{\mathrm{a}}$ & ,433 &, 419 &, 380 \\
\hline
\end{tabular}

a. Preictors: (Constant), oldpeak, fbs, chol, cp , sex , Age , exan

value in Table 8 , the independent variables can be arranged in order of impact level. A one-unit increase in the $\mathrm{Cp}$ value takes the first place in the effect level because it causes an increase of 0.294 in the standard deviation of the heart attack prediction. Since a one-unit increase in Oldpeak value will cause a 0.277 decrease in the standard deviation of the heart attack estimate, it is in the last place in the effect level. By making this interpretation in other variables, the effect level order was determined as $\mathrm{Cp}$, Fbs, Chol, Age, Exang, Sex, Oldpeak.
Table 6 Anova test results

\begin{tabular}{|c|c|c|c|c|c|}
\hline \multicolumn{7}{|c|}{ ANOVA $^{\text {a }}$} \\
\hline Model & $\begin{array}{l}\text { Sum of } \\
\text { Squares }\end{array}$ & df & $\begin{array}{l}\text { Mean } \\
\text { Square }\end{array}$ & F & Sig. \\
\hline Regression & 32,505 & 7 & 4,644 & 32,123 &, $000^{\mathrm{b}}$ \\
\hline Residual & 42,644 & 295 & 0,145 & & \\
\hline Total & 75,149 & 302 & & & \\
\hline
\end{tabular}

a. DependentVariable: kalpkrizi

b. Predictors: (Constant), oldpeak, fbs, chol , cp, sex , Age , exang

Table 7. "Descriptive Statistics" results DescriptiveStatistics

\begin{tabular}{|c|c|c|c|}
\hline & Mean & Std. Deviation & N \\
\hline kalpkrizi &, 54 &, 499 & 303 \\
\hline Age & 54,37 & 9,082 & 303 \\
\hline sex &, 68 &, 466 & 303 \\
\hline cp &, 97 & 1,032 & 303 \\
\hline chol & 246,26 & 51,831 & 303 \\
\hline fbs &, 15 &, 356 & 303 \\
\hline exang &, 33 &, 470 & 303 \\
\hline oldpeak & 1,040 & 1,1611 & 303 \\
\hline
\end{tabular}

Table 8. "Coefficients" results

\begin{tabular}{|c|c|c|c|c|c|c|c|c|c|c|c|c|}
\hline \multicolumn{13}{|c|}{ Coefficients $^{\mathrm{a}}$} \\
\hline \multirow[t]{2}{*}{ Model } & \multicolumn{2}{|c|}{$\begin{array}{l}\text { Unstandardized } \\
\text { Coefficients }\end{array}$} & \multirow{2}{*}{$\begin{array}{l}\begin{array}{l}\text { Standardized } \\
\text { Coefficients }\end{array} \\
\text { Beta } \\
\end{array}$} & \multirow[t]{2}{*}{$\mathbf{t}$} & \multirow[t]{2}{*}{ Sig. } & \multicolumn{2}{|c|}{$\begin{array}{l}\text { 95,0\% Confidence } \\
\text { Inter val for B }\end{array}$} & \multicolumn{3}{|c|}{ Correlations } & \multicolumn{2}{|c|}{$\begin{array}{l}\text { Collinearity } \\
\text { Statistics }\end{array}$} \\
\hline & B & $\begin{array}{l}\text { Std. } \\
\text { Error }\end{array}$ & & & & $\begin{array}{l}\text { Lower } \\
\text { Bound }\end{array}$ & $\begin{array}{l}\text { Upper } \\
\text { Bound }\end{array}$ & $\begin{array}{l}\text { Zero- } \\
\text { order }\end{array}$ & Partial & Part & Tolerance & VIF \\
\hline (Constant) & 1,309 &, 171 & & 7,658 &, 000 &, 972 & 1,645 & & & & & \\
\hline Age &,- 008 & ,003 &,- 138 & $\begin{array}{c}- \\
2,974\end{array}$ & ,003 &,- 013 &,- 003 &,- 225 &,- 171 & $\begin{array}{c}- \\
130\end{array}$ & ,892 & 1,122 \\
\hline $\operatorname{sex}$ &,- 252 & ,049 &,- 236 & 5,161 & , 000 &,- 349 &,- 156 &,- 281 &,- 288 & 226 & ,922 & 1,084 \\
\hline $\mathrm{cp}$ & , 142 &, 023 & ,294 & 6,112 &, 000 & ,096 & , 188 & ,434 & ,335 & ,268 & ,829 & 1,206 \\
\hline chol &, 000 &, 000 &,- 052 & $\begin{array}{c}- \\
1,129\end{array}$ & ,260 &,- 001 &, 000 &,- 085 &,- 066 & , & ,915 & 1,093 \\
\hline fbs &,- 030 &, 062 &,- 021 &,- 478 & ,633 &,- 153 & ,093 &,- 028 &,- 028 & , & ,967 & 1,034 \\
\hline exang &,- 202 &, 053 &,- 190 & $\begin{array}{c}- \\
3,812 \\
\end{array}$ & ,000 &,- 306 &,- 098 &,- 437 &,- 217 & $\begin{array}{c}- \\
, 167 \\
\end{array}$ &, 775 & 1,291 \\
\hline oldpeak &,- 119 &, 020 &,- 277 & $5, \overline{-}$ & ,000 &,- 159 &,- 080 &,- 431 &,- 326 & , 260 & ,876 & 1,142 \\
\hline
\end{tabular}

a. DependentVariable: kalpkrizi

\section{Conclusion}

Heart attack is a very common health problem worldwide. According to researches, the number 1 cause of deaths is heart attack. Therefore, many studies have been done in the literature and are still being done. Different techniques were used in these studies. Artificial neural networks, data mining, fuzzy logic, deep learning are just a few of these techniques.

In this study, the fuzzy logic method, which is widely used in the diagnosis, treatment and risk estimation of many diseases in the field of health, was used.7 input parameters and 1 output parameter were used and a fuzzy model was created. At the end of the study, the data of 10 patients were shown in the model and whether they would have a heart attack or not was given as an output. Multiple regression analysis was conducted to determine the effect of other independent variables on the prediction of heart attack, which is the dependent variable, and to examine the relationship between them. According to the regression results, it is seen that the fuzzy logic equation significantly predicts the heart attack.

In the future, it is expected that studies will be carried out on different diseases using fuzzy logic method. In line with these studies, fuzzy logic will be of vital importance by increasing efficiency in health services and will become a powerful tool.

\section{Author Statements:}

- The authors declare that they have equal right on this paper.

- The authors declare that they have no known competing financial interests or personal 
relationships that could have appeared to influence the work reported in this paper

- The authors declare that they have no-one to acknowledge.

\section{References}

[1] Lu, L., Liu, M., Sun, R., Zheng, Y. and Zhang, P. "Myocardial Infarction: Symptoms and Treatments". Cell Biochem Biophys 72(2015), 865-867.

[2] Devlin, R.J. and Henry, J.A. "Clinical review: Major consequences of illicit drug consumption". Critical Care, 12, 1(2008), 202.

[3] Jensen, G., Nyboe, J., Appleyard, M. and Schnohr, $P$. "Risk factors for acute myocardial infarction in Copenhagen, II: Smoking, alcohol intake, physical activity, obesity, oral contraception, diabetes, lipids, and blood pressure". Europen Heart Journal, 12, 3(1991), 298-308.

[4] Sağlık Bakanlığı, Türkiye kalp ve damar hastalıklarını önleme ve kontrol programı. Birincil, ikincil, üçüncül korumaya yönelik stratejik plan ve eylem planı (2010-2014), T.C. Sağlık Bakanlığı, Temel Sağlık Hizmetleri Genel Müdürlüğü. Yayın No: 812. Ankara-Turkey. Anıl Matbaas1. (4-30)

[5] Kannel, W.B., D’Agostino, R.B., Sullivan, L. and Wilson, P.W.F. "Concept and usefulness of cardiovascular risk profiles". American Heart Journal, 148(2004), 16-26.

[6] Kasapoğlu, E.S. and Enç, N. "A Guide for Coronary Artery Patients". Journal of Cardiovascular Nursing, 8, 15(2017)1-7.

[7] Kosuge, M.,Kimura, K., Ishikawa, T., Ebina, T., Hibi, K., Tsukahara, K., Kanna, M., Iwahashi, N., Okuda, J., Nozawa, N., Ozaki, H., Yano, H., Nakati, T., Kusama, I. and Umemura, S. "Differences Between Men and Women in Terms of Clinical Features of ST-Segment Elevation Acute Myocardial Infarction". Circulation Journal, 70, 3(2006)222-226.

[8]World Health Organization, (2017), Cardiovascular diseases (CVDs): keyfacts. Erişim tarihi: 9 Ekim 2020 https://www.who.int/en/news-room/factsheets/detail/cardiovascular-diseases-(cvds)

[9] Güleç, S. "Kalp Damar Hastalıklarında Global Risk Ve Hedefler". Arch Turk Soc Cardiol, 37, 2(2009)1-10.

[10]World Health Organization, (2020), Tobacco responsible for $20 \%$ of deaths from coronary heart disease, date: 10 October 2020 https://www.who.int/news/detail/22-09-2020tobacco-responsible-for-20-of-deaths-fromcoronary-heart-disease

[11] T.C. Sağlık Bakanlı̆̆ı, Türkiye Kalp ve Damar Hastalıkları Önleme ve Kontrol Programı Eylem Planı (2015-2020), date: 9 October 2020 https://tkd.org.tr/TKDData/Uploads/files/Turkiyekalp-ve-damar-hastaliklari-onleme-ve-kontrolprogrami.pdf
[12] Onat, A. "Risk factors and cardiovascular disease in Turkey". Atherosclerosis, 156(2001), 1-10.

[13] Zadeh, L.A. "Fuzzy Sets". Information and Control, 8, 3(1965),338-353.

[14] Kumar, S. and Kaur, G. "Detection of Heart Diseases using Fuzzy Logic". International Journal of Engineering Trends and Technology (IJETT), 4, 6(2013)2694-2699.

[15] Lee, C.S. and Wang, M.H. "A fuzzy expert system for diabetes decision support application". IEEE Transactions on Systems Man and Cybernetics, 41, 1(2011)139-153.

[16] Rustempasic, I. and Can, M. "Diagnosis of Parkinson's Disease using Fuzzy C-Means Clustering and Pattern Recognition". Southeast Europe Journal of Soft Computing, 2, 1(2013)4249.

[17] Samuel, O. W., Omisore, M. O. and Ojokoh, B.A. "A web based decision support system driven by fuzzy logic for the diagnosis of typhoid fever". Expert Systems with Applications, 40, 10(2013)4164-4171.

[18] Biyouki, S.A., Turksen, I.B. and FazelZarandi, M.H. "Fuzzy rule-based expert system for diagnosis of thyroid disease". In Proceedings of 2015 IEEE conference on computational intelligence in bioinformatics and computational biology (CIBCB), Canada, pp. 1-7 (2015).

[19] Thakur, S., Raw, S.N. and Sharma, R. "Design of a fuzzy model for thalassemia disease diagnosis: Using mamdani type fuzzy inference system". International Journal of Pharmacy and Pharmaceutical Sciences, 8, 4(2016)356-361.

[20] Saikia, D. and Dutta, J.C. "Early diagnosis of dengue disease using fuzzy inference system". In Proceedings of 2016 international conference on micro electronics, computing and communications (MicroCom), Durgapur- India, pp. 1-6 (2016).

[21] Torun, S. “Koroner Kalp Hastalığı Riski Tanısı Ve Tedavisi İçin Hiyerarşik Bir Bulanık Uzman Sistem Tasarımı". Selçuk Üniversitesi, Fen Bilimleri Enstitüsü, Yüksek Lisans Tezi, KonyaTurkey (2007).

[22] Palaniappan, S. and Awang, R. "Intelligent heart disease prediction system using data mining techniques". International Journal of Computer Science and Network Security, 8, 8(2008)108115.

[23] Patil, S.B. and Kumaraswamy, Y.S. "Intelligent and effective heart attack prediction system using data mining and artificial neural network". European Journal of Scientific Research, 31, 4(2009)642-656.

[24] Adeli, A. and Neshat, M. "A fuzzy expert system for heart disease diagnosis". Proceedings of the International MultiConference of Engineers and Computer Scientists, Hong Kong-China. (2010)

[25] Bhatla, N. and Kiran, J. "A novel approach for heart disease diagnosis using data mining and fuzzy logic". International Journal of Computer Applications, 54, 17(2012) 16-21. 
[26] Devi, Y.N. and Anto, S. "An evolutionary-fuzzy expert system for the diagnosis of coronary artery disease". International Journal of Bio-Science and Bio-Technology, 3, 4(2014), 1478-1484.

[27] Ali, F. El-Sappagh, S., RiazulIslam, S.M., Kwak, D., Ali, A., Imran, M. and Kwak, K.S. "A smart health care monitoring system for heart disease prediction based on ensemble deep learning and feature fusion". Information Fusion, 63(2020), 208-222.

[28] Ertunç, H.M. "Introduction to Fuzzy Logic". Kocaeli Üniversitesi, Kocaeli-Turkey 2012 (in Turkish).

[29] Ross, T.J "Fuzzy Logic with Engineering Applications". New York: Wiley-Blackwell. (2016).

[30] Syropoulos, A. and Grammenos, T. "A Modern Introduction to Fuzzy Mathematics". New York: Wiley (2020).

[31] Demirhan, A., Kılıç, Y.A. and Güler, İ. "Tıpta Yapay Zeka Uygulamaları". Artificial Intelligence Applications in Medicine, 9, 1(2010)31-41.

[32] Şahinler, S., Görgülü, Ö. and Bek, Y. "Sağlık Alanında Bulanık Mantık Yöntemlerinin Uygulanabilirliği”. IX.Ulusal Biyoistatistik Kongresi, Zonguldak-Turkey. (2006).

[33] Danish, E. and Onder, M. "Application of Fuzzy Logic for Predicting of Mine Fire in Underground Coal Mine". Safety and Health at Work, 11, 3(2020)322-334.

[34] Nilashi, M., Ibrahım, O., Ahmadi, H. and Shahmoradi, L. "A knowledge-based system for breast cancer classification using fuzzy logic method". Telematics and Informatics, 34, 4(2017) 133-144.

[35] Anooj, P.K.. "Clinical decision support system: Risk level prediction of heart disease using weighted fuzzy rules". Journal of King Saud University - Computer and Information Sciences, 24, 1(2012) 27-40.

[36] Sarı, M., Murat, Y. and Kirabalı, M. "Bulanık Modelleme Yaklaşımı Ve Uygulamaları". Journal of Science and Technology of Dumlupınar University, 009(2005) 77-92.

[37] Keskenler, M.F. and Keskenler, E.F. "Bulanık Mantığın Tarihi Gelişimi”. Takvim-i Vekayi, 5, 1(2017) 1-10.

[38] Malmir, B., Amini, M. and Chang, S.I. "A medical decision support system for disease diagnosis under uncertainty". Expert Systems with Applications, 88(2017) 95-108

[39] Baykal, N. and Beyan, T. "Bulanık Mantık İlke ve Temelleri”. Ankara: Bıçaklar Kitabevi. (2004).

[40] Abbod, M.F., vonKeyserlingk, D.G., Linkens, D.A. and Mahfouf, M. "Survey of utilisation of fuzzy technology in medicine and healthcare". Fuzzy Sets and Systems, 120, 2(2001) 331-349.

[41] Phuong, N.H. and Kreinovich, V. "Fuzzy logic and its applications in medicine". International Journal of Medical Informatics, 62, 23(2001)165-173.

[42] Mamdani, E.H. and Assilian, S. “An experiment in linguistic synthesis with a fuzzy logic controller". International Journal of Man-Machine Studies, 7, 1(1975) 1-13.

[43] Chang, P.C., Fan, C.Y. and Lin, J.J. "Monthly Electricity Demand Forecasting Based on a Weighted Evolving Fuzzy Neural Network Approach". Electrical Power and Energy Systems, 33, 1(2011) 17-27.

[44] Günaşd1, N.E. "Çok Değişkenli Çoklu Doğrusal Regresyon Analizinin İncelenmesi”. Atatürk Üniversitesi, Fen Bilimler Enstitüsü, Yüksek Lisans Tezi, Erzurum-Turkey 2014 (in Turkish). 